
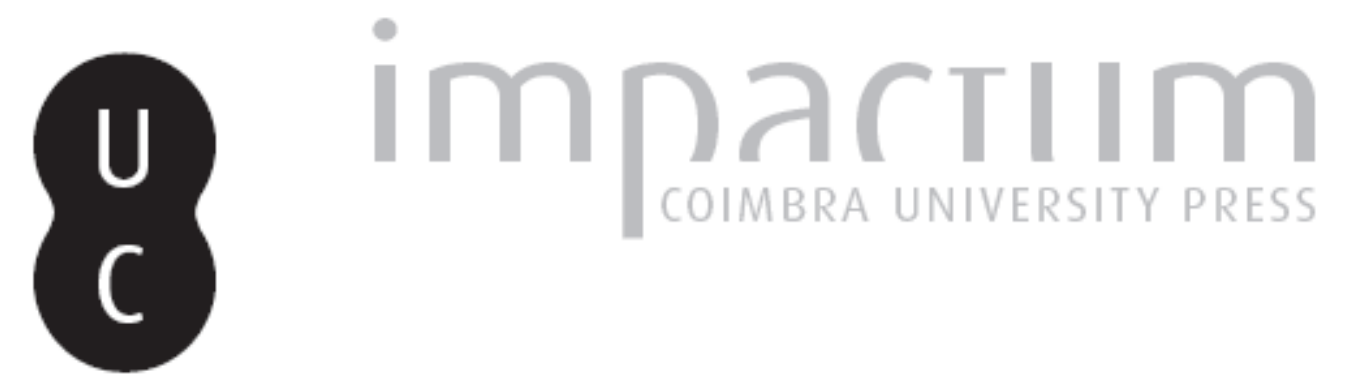

[Recensão a] Baum, Nathhalie - Le Temple d'Edfou: à la découverte du Grand Siège
de Rê-Harakhty Autor(es): $\quad$ Sousa, Rogério

Publicado por: Centro de História da Universidade de Lisboa

URL persistente:

URI:http://hdl.handle.net/10316.2/23801

DOI:

DOI:http://dx.doi.org/10.14195/0871-9527_19_24

Accessed : $\quad$ 26-Apr-2023 15:32:53

A navegação consulta e descarregamento dos títulos inseridos nas Bibliotecas Digitais UC Digitalis, UC Pombalina e UC Impactum, pressupõem a aceitação plena e sem reservas dos Termos e Condições de Uso destas Bibliotecas Digitais, disponíveis em https://digitalis.uc.pt/pt-pt/termos.

Conforme exposto nos referidos Termos e Condições de Uso, o descarregamento de títulos de acesso restrito requer uma licença válida de autorização devendo o utilizador aceder ao(s) documento(s) a partir de um endereço de IP da instituição detentora da supramencionada licença.

Ao utilizador é apenas permitido o descarregamento para uso pessoal, pelo que o emprego do(s) título(s) descarregado(s) para outro fim, designadamente comercial, carece de autorização do respetivo autor ou editor da obra.

Na medida em que todas as obras da UC Digitalis se encontram protegidas pelo Código do Direito de Autor e Direitos Conexos e demais legislação aplicável, toda a cópia, parcial ou total, deste documento, nos casos em que é legalmente admitida, deverá conter ou fazer-se acompanhar por este aviso.

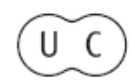



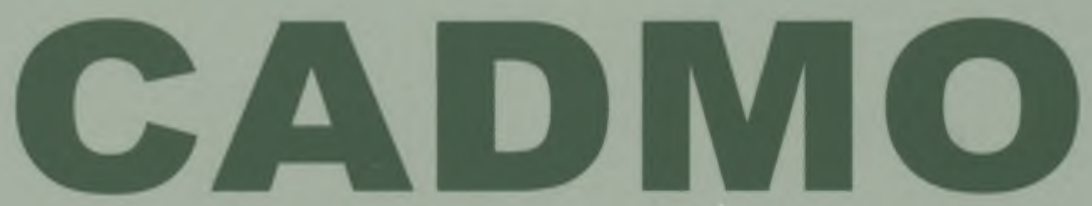

Revista de História Antiga

\author{
Centro de História \\ da Universidade de Lisboa
}

19

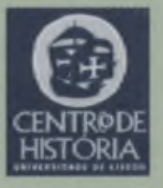

430 =

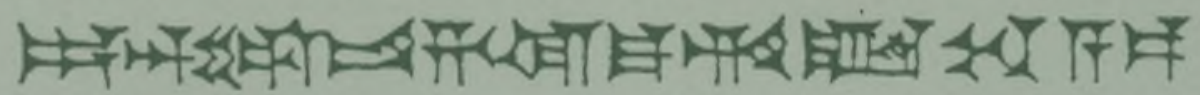

MHNIN AEI $\Delta$ E $\Theta E A ~ \Pi H \Lambda H I A \triangle E \Omega$ 
não impediu que a alquimia desse um poderoso impulso à química emergente, nem que alguns reputados físicos, como Isaac Newton, tivessem continuado a revelar um profundo interesse pelos textos alquímicos.

Apesar de refutada pelos critérios científicos da ciência dominante, a alquimia continuou a gozar de um vivo interesse, continuando a suscitar, ao longo dos séculos XVIII e XIX, inúmeras publicações e reedições. No capítulo $V$ ("Between occultism and enlightenment»), o Autor evidencia o interesse suscitado pela alquimia no contexto da maçonaria e do movimento Rosa-cruz. Sobretudo a partir da segunda metade do século XVIII, com os escritos de Ignaz Edler von Born, uma suposta tradição "egípcia" tornou-se na matriz filosófica da maçonaria que até aí revia as suas origens apenas até aos cavaleiros templários e ao templo de Jerusalém.

Finalmente, no capítulo VI ("Systems and esoterica»), o autor sublinha o papel do trabalho de autores como Julius evola, mas sobretudo de Umberto Eco e de Heinrich Rombach para a renovação do estudo filosófico do hermetismo. E se Eco deu um contributo notável para a correcta delimitação epistemológica do hermetismo no contexto da sua matriz helenista original, Rombach formulou toda uma singular formulação filosófica em torno do "fenómeno hermético".

No seu conjunto, o trabalho de Florian Ebeling constitui uma síntese notável da história das representações associadas a Hermes Trimeguisto e que em grande medida estabelece as bases para 0 estudo científico do hermetismo, um estudo que, tendo em conta o lastro que deixou no pensamento ocidental, se afigura de um interesse inegável para a compreensão da cultura europeia.

\section{Rogério Sousa}

NATHALIE BAUM, Le Temple d'Edfou: À la découverte du Grand Siège de Rê-Harakhty, Monaco: Éditions du Rocher, 2007, 635 pp., ISBN 978-2-268-05795-8.

Neste volume, a Autora conduz o leitor ao coração do templo de Hórus de Edfu apresentando, ao longo dos oito capítulos do livro, cada uma das câmaras que rodeiam o santuário principal do deus. Trata-se da região mais sagrada do templo e a que mais envolta estava pelo carácter sacramental do rito e do mito que, na época em 
que foi construído, o período ptolemaico, atingia uma complexidade sem precedentes. A Autora escolheu, portanto, como objecto de estudo, um dos espaços mais notáveis do Antigo Egipto, quer pelo seu grau de preservação, quer pelo nível de elaboração que, nesse momento histórico em particular, atingiu a reflexão teológica em torno do espaço sagrado. Evidentemente que existiam já outras obras de referência que documentam os textos e as representações dispostas ao longo das paredes do templo de Edfu. A começar pelas monumentais publicações do Institut Français d'Archéologie Orientale e passando pelas obras de Alliot e de Cauville, as quais são obviamente utilizadas como importante recurso bibliográfico, como a própria Autora declara logo na Introdução.

A principal virtude deste livro consiste precisamente em apresentar num único volume um conjunto de informações que até ao momento estavam dispersas por um conjunto de obras difíceis de obter, inclusivamente nas principais bibliotecas do nosso país. Seguindo uma metodologia rigorosamente descritiva, a Autora introduz o leitor em cada uma das câmaras que rodeiam o santuário central. Começando pela câmara de Mesen, situada no eixo do templo, imediatamente a norte do santuário central (capítulo I), a visita proposta pela Autora é conduzida de acordo com a sequência apresentada pelos próprios textos redigidos no próprio santuário, insinuando assim um percurso ritual e mítico cuidadosamente codificado. A visita prossegue para as capelas situadas à direita do santuário principal: as câmaras osiríacas (capítulo II), o santuário de Chetit (capítulo III), a câmara do trono dos deuses (capítulo IV) e a câmara dos toucados (capítulo V). Retomando a câmara setentrional, o percurso ritual prossegue agora pelas capelas que contornam o santuário central pela esquerda: seguem-se as câmaras lunares (capítulo 6), a câmara do trono de Ré (capítulo 7) e a câmara da Behdet de Ré (capítulo 8).

Em cada capítulo a Autora apresenta uma minuciosa descrição das cenas aí reportoriadas e elabora uma aturada associação das cenas rituais com os eventos míticos que pretendem reactualizar. A obra apresenta um conjunto de anexos documentais que facilitam a visualização das cenas descritas ao longo do texto, bem como de um útil conjunto de índices que facilitam a utilização deste volume como instrumento de trabalho. Trata-se, no seu conjunto, de um instrumento de trabalho muito útil. 